JoNes: For the scattered power received back at the receiver.

T. Hughes reported work by a graduate student at the Institute for Arctic and Alpine Research on numerical modelling of the Barnes Ice Cap which indicated different dynamic states in two portions of the ice cap over the last century as also suggested by the work of Holdsworth.

\title{
REFERENCES
}

Boned, C., and Barbier, A. 1973. A study of the change with time of the dielectric properties of polycrystalline ice. (In Whalley, E., and others, ed. Physics and chemistry of ice: papers presented at the Symposium on the Physics and Chemistry of Ice, held in Ottawa, Canada, I4-18 August 1972. Edited by E. Whalley, S. F. Fones, L. W. Gold. Ottawa, Royal Society of Canada, p. 208-I I.)

Evans, S. 1965. Dielectric properties of ice and snow-a review. Journal of Glaciology, Vol. 5, No. 42, p. 773-92.

Fitzgerald, W. J., and Paren, J. G. 1975. The dielectric properties of Antarctic ice. Fournal of Glaciology, Vol. i 5 , No. 73 , p. $39-48$.

Paren, J. G. 1973. The electrical behavior of polar glaciers. (In Whalley, E., and others, ed. Physics and chemistry of ice: papers presented at the Symposium on the Physics and Chemistry of Ice, held in Ottawa, Canada, $14^{-18}$ August 1972. Edited by E. Whalley, S. J. Jones, L. W. Gold. Ottawa, Royal Society of Canada, p. 262-67.)

\section{RADIO-ECHO SOUNDING ON SOUTH CASCADE GLACIER, WASHINGTON, USING A LONG-WAVELENGTH, MONO-PULSE SOURCE}

\author{
By Raymond D. Watts, Anthony W. England, \\ (U.S. Geological Survey, Denver, Colorado 80225, U.S.A.) \\ Roger S. Vickers \\ (Stanford Research Institute, Menlo Park, California 94025, U.S.A.) \\ and Mark F. Meier \\ (U.S. Geological Survey, Tacoma, Washington 98402, U.S.A.)
}

Abstract. A short-pulse, long-wavelength radio-echo sounder has successfully measured the ice depth on the South Cascade Glacier. Depths up to $250 \mathrm{~m}$ were determined with resolution of about $5 \%$. Bottom returns were clear and almost never ambiguous. Their accuracy was confirmed by comparison with hot-point drilling results. The secret for successful sounding in temperate glaciers is the use of a sufficiently low center frequency. Five megahertz was most successful. Tests at $15 \mathrm{MHz}$ indicated an increase in coherent clutter which rendered the bottom return observable only with prior knowledge of its location. The cause of the clutter is probably water-filled voids in the ice which behave as Rayleigh scatterers.

The sounding system consists of an avalanche-transistor transmitter, which delivers a pulse to an acute-angle crossed-wire antenna. The pulse is shaped and given its centerfrequency characteristics by the resonant properties of the antenna. The transmitting and receiving antennas are identical, consisting of wires and lumped resistors. The resistors reduce antenna ringing, thereby maintaining as short a pulse as possible. The receiver consists of an oscilloscope and a Polaroid camera. No preamplification is required for depths up to $250 \mathrm{~m}$, but may be necessary for deeper glaciers. 


\section{DISCUSSION}

D. F. PAGE: What is your estimate of the power levels being transmitted in your experiments? R. D. WAtrs: On South Cascade Glacier, peak power was $\approx 400$ W. On Columbia Glacier, it was increased to $\approx 4$ ooo W.

M. V. BERry: What deconvolution procedure have you used to take account of echoes arriving obliquely?

Watrs: We have taken the initial (vertical) depths, estimated preliminary slopes, and projected the observed reflection distances onto these slopes. This results in a sideways displacement of the reflection point. Without a greater density of points, it is difficult to do a Harrison-type bottom-topography transformation.

M. F. MeIER: I should point out that the deconvolution of the South Cascade traverse data was strictly two-dimensional; if there were shallower reflectors to either side of the profile these might explain the discrepancy between bore-hole and radar results.

D. J. Drewry: How sure are you that the reflecting targets for the radio-echo measurements correspond to the ice/bedrock interface identified from the bore-hole data?

WAтTs: This is a question to which we do not know the answer. The only variation of properties near the bottom of the glacier is the compositional difference of the sole material. This difference extends over some tens of centimetres and not about ten metres which would be required to provide the higher radio echo.

W. S. B. Paterson: What area of the glacier bed does your antenna illuminate?

WATTS: From nadir out to about $45^{\circ}$ - a very large area.

PAterson: Do you know whether your bore holes are vertical?

Meier: The hot points were about two to three metres long and had no pendulum or other steering arrangement, thus we cannot be sure the holes were straight and vertical. This also might explain the discrepancy between hot point and radar depths, as could several other possible phenomena. G. DE Q. RobIn: Can you give us a preliminary estimate of the size of the scattering centres
within the ice mass.

WATTs: During the thermal drilling program on South Cascade Glacier, one $0.5 \mathrm{~m}$ to $1.0 \mathrm{~m}$ diameter void was encountered approximately every $400 \mathrm{~m}$ of drilling. This results in a statistical expectation of a $0.1 \%$ volume fraction of water in the glacier. Putting these parameters into the scattering theory of Smith and Evans (1972) we get scattered power levels which are roughly the same as we observed. The way to resolve the scatterer size and orientation distribution is to use many frequencies and multiple polarizations.

J. G. PARen: If you are uncertain as to the correct value for the dielectric constant of a temperate glacier, you could obtain it for the surface layers at least by the time delay between the air wave and surface wave. This would give you the correct permittivity for depth sounding in the low $\mathrm{MHz}$ range if the glacier was uniform with depth.

WAtTs: On South Cascade Glacier we worked on a snow-covered area. In this case, the airwave-ground-wave delay would be unlikely to relate well to the electrical properties deep in the glacier. On Columbia Glacier we worked on blue ice. We could have made the ground-wave velocity measurement, but did not. There the ice should have been uniform with depth. 
T. Hughes: Professor Lliboutry has postulated a substantial temperate ice layer above the bed for parts of the Antarctic ice sheet. What modifications, in wave length, power, etc. of your system would you recommend to get good internal and basal reflections in cases where a cold layer overlies a temperate ice layer, both of substantial thickness?

WATTS: If other radio-echo sounding systems are capable of obtaining good reflections, you should stick with them. Our system should be able to penetrate fairly deep polar ice, but if the temperate layer is deep, the power may have to be increased. Frequencies of $\mathrm{I}$ to $5 \mathrm{MHz}$ should still be adequate.

\title{
REFERENCE
}

Smith, B. M. E., and Evans, S. 1972. Radio echo sounding: absorption and scattering by water inclusion and ice lenses. Fournal of Glaciology, Vol. i 1, No. 61, p. 133-46.

\section{THE STUDY OF FRESH-WATER LAKE ICE USING MULTIPLEXED IMAGING RADAR}

\author{
By M. Leonard Bryan and R. W. Larson \\ (Radar \& Optics Division, Environmental Research Institute of Michigan, P.O. Box 6r8, \\ Ann Arbor, Michigan 48107 , U.S.A.)
}

Abstract. The study of ice in the upper Great Lakes, both from the operational and the scientific points of view, is receiving continued attention. Both quantitative and qualitative field work is being conducted to provide the needed background for accurate interpretation of remotely sensed data. The sensor data under discussion in this paper were obtained by a side-looking multiplexed airborne radar (SLAR). These were supplemented with groundtruth data.

Radar, due to its ability to penetrate adverse weather, is an especially important instrument for monitoring ice in the upper Great Lakes. It has been previously shown that imaging radars can provide maps of ice cover in these areas. However, questions concerning both the nature of the surfaces reflecting radar energy and the interpretation of the radar imagery continually arise.

Our analysis of ice in Whitefish Bay (Lake Superior) indicated that the combination of the ice/water interface with the ice/air interface is the major contributor to the radar backscatter as seen on the imagery. The ice has a very low dielectric constant $(<3.0)$ and a low loss tangent. Thus, this ice is somewhat transparent to the energy used by the imaging SLAR system. The ice types studied include newly formed black ice, pancake ice, and frozen and consolidated pack and brash ice.

Although ice thickness cannot be measured directly from the received signals, it is suspected that by combining the radar backscatter information with both meteorological and sea-state history of the area and with some basic ground truth, better estimates of the ice thickness may be provided. In addition, certain ice features (e.g. ridges, ice foots, areas of brash ice) may be identified with reasonable confidence. There is a continued need for additional ground work to verify the validity of imaging radars for these types of interpretations.

This paper is being published in full in another issue of the fournal of Glaciology. 